\title{
Micromycetes contaminating nuts used for food
}

\author{
Aurimas Krasauskas ${ }^{1 \star}$, \\ Aurelija Paulauskien $\dot{e}^{2}$, \\ Živilè Tarasevičiené $\dot{e}^{2}$ \\ ${ }^{1}$ Institute of Biology and Plant Biotechnology, \\ Aleksandras Stulginskis University, \\ Studentu St. 11, \\ LT-53361 Kaunas-Akademija, Lithuania \\ ${ }^{2}$ Institute of Agricultural and Food Science, \\ Aleksandras Stulginskis University, \\ Studentu St. 11, \\ LT-53361 Kaunas-Akademija, Lithuania
}

\begin{abstract}
Nuts are one of the most delicious and nutritious foods, but due to the extremely high fat, protein and low water content they are quite refractory to spoilage by microorganisms. In this study a wide range of microorganisms was recorded. The samples were collected from 6 different markets in Kaunas, Lithuania. The moisture content of nuts was determined by drying the samples in an oven at $103( \pm 2){ }^{\circ} \mathrm{C}$ temperature for 6 hours. Dilution plating (a surface-spread method) was used for colony counting. The analyses of nut samples revealed that imported nuts were quite intensely contaminated with propagules of various fungi species. The moisture content in the nuts varied in dependence of their type and acquisition place. The highest moisture content was observed in walnuts, $13.93 \%$, while almost twice less in pistachio and hazelnuts, 6.38 and $6.76 \%$, respectively. The least number of colony forming units (cfu) of fungi was detected in hazelnuts $\left(9.11 \times 10^{3} \mathrm{cfu} / \mathrm{g}\right)$ followed by peanuts $\left(11.46 \times 10^{3} \mathrm{cfu} / \mathrm{g}\right)$. In contrast, walnuts $\left(20.90 \times 10^{3} \mathrm{cfu} / \mathrm{g}\right) \mathrm{rep}-$ resented the highest infections of fungi. A total of 8 different fungal genera (Aspergillus spp. Acremonium spp., Cladosporium spp., Fusarium spp., Mucor spp., Rhizopus spp., Paecilomyces spp., and Penicillium spp.) and 16 species were isolated. Aspergillus, Mucor and Penicillium genera were more frequently detected than other genera of fungi. Aspergillus spp. was found in the most investigated nut samples. The greatest diversity of micromycetes was detected in hazelnuts and walnuts.
\end{abstract}

Key words: Aspergilus, hazelnuts, moisture content, peanuts, pistachio, walnuts

\section{INTRODUCTION}

Nuts are globally recognized as a nutritionally important food, being high in proteins, vitamins and minerals such as potassium, iron, vitamin E,

\footnotetext{
* Corresponding author. E-mail: Aurimas.Krasauskas@asu.lt
}

thiamine, niacin, riboflavin and unsaturated fats. Various nuts are used as a raw material in many industries as well as for direct consumption (Abdulla, 2013).

During maturation in the field, nuts are exposed to a variety of environmental conditions that increase the risk of fungal contamination. 
The outer shell of nuts affords natural protection against the most contaminating agents such as insects and microorganisms, making the nutmeat virtually microbe-free (International Commission on Microbiological Specifications for Foods, 1998). After the nuts are harvested, appropriate conditions and materials are necessary to protect against spoilage during storage ant transport. High temperatures, humid conditions and extreme temperature gradients during storage and transport can increase the susceptibility of nuts to spoilage (International Commission on Microbiological Specifications for Foods, 1998). Nuts require cool and dry conditions to maintain their low moisture content. After postharvest used drying technologies nuts contain approximately $8 \%$ moisture and have an approximate water activity of 0.7. This low moisture content minimizes spoilage concerns due to bacteria. However, this along with low-soluble carbohydrate levels and hygroscopic properties creates a favourable environment for the survival of moulds (Compendium of the Microbiological Spoilage of Foods and Beverages, 2009). Due to extremely high fat and protein of various nuts products are quite refractory to spoilage by microorganisms. Mould can grow upon them if they are stored under conditions that permit sufficient moisture for their propagation (Phillips et al., 1979; Frank, 1981). Processing is also a critical factor in controlling nut spoilage. Shelling and other processing such as chopping and slicing can increase contamination of nutmeat with fungi.

Many of dried nuts are favourable for the storage moulds such as Eurotium spp., Aspergillus spp., Penicillium spp., and Wallemia spp. Hazelnuts are most susceptible to Rhizopus spp., Penicillium spp., Aspegillus spp. contamination during harvest, postharvest handling and storage. In freshly harvested pistachios Fusarium (particularly F. equiseti and F. acuminatum) and Alternaria species are also important components of the postharvest microbiota (Hocking, Pitt, 1996). The intimate contact of soil with the shells of developing peanuts is an ideal situation for fungal colonisation. Aspergillus species, particulary A. niger and A. flavus, have been reported frequently. Previous studies showed that 30.97 million tons of greasy seed products, mainly pistachio and peanut, of different Asian and African countries were contaminated by $A$. flavus and $A$. parasiticus (Christensen, Meronuck, 1986; Dekoe et al., 2000; D’Mello, Macdonald, 1998). Other commonly occurring fungi in peanuts are Fusarium (F. solani, F. semitectum, F. oxysporum), Penicillium (P. funiculosum, $P$. chrysogenum, $P$. citrinum, $P$. aurantiogriseum), Rhizopus (R. oryzae, $R$. stolonifer), Rhizoctonia solani, Macrophomina phaseolina, Chaetomium and Culvularia species (King et al., 1981; Pitt et al., 1992; Hocking, Pitt, 1996).

Mould contamination in the nuts is prevalent and mycotoxin contamination is a significant food safety issue due to serious adverse effects on human health (Raudoniene, Lugauskas, 2005). A major problem related to fungal attack in nuts is the production of toxic secondary metabolites, particularly fumonisin, zearalenone and aflatoxin, produced by F. verticillioides, F. graminearum and A. flavus, respectively (Scott, 1993). Aflatoxin has powerful teratogenic, mutagenic and hepato-carcinogenic effects (Wang et al., 2001). Aflatoxins were detected in $90 \%$ of hazelnut samples at levels of $25-175 \mu \mathrm{g} \mathrm{kg}^{-1}$ and in $75 \%$ of wallnut samples. Mycotoxins can cause toxic effects on human and animal tissue and organs. They are among the 21 st century major concerns due to their important role (Jay et al., 2005).

The aim of the study was to evaluate the spread of micromycetes and assess a risk related with consumption of nuts supplied in the market. Even though some of these fungi are not toxigenic, contamination with different $A s$ pergillus, Fusarium and Penicillium spp. should be monitored for maintenance of foodstuff hygiene and safety.

\section{MATERIALS AND METHODS}

Unshelled hazelnuts (Corylus sp.), peanuts (Arachis sp.), pistachio (Pistacia vera), walnuts (Juglans sp.) were collected from 6 different markets in Kaunas, Lithuania. Moisture content of nuts was determined by drying the samples in an oven at $103( \pm 2){ }^{\circ} \mathrm{C}$ temperature for 6 hours. 
The moisture content of the sample was calculated as percentage (\%) difference between the sample before and after drying (Pitt et al., 1992). Dilution plating (a surface-spread method) (Pitt, Hocking, 1997) was used for colony counting. $10 \mathrm{~g}$ of each milled nut sample were homogenized with $90 \mathrm{ml}$ sterile water for $30 \mathrm{~min}$ in an orbital shaker. Serial decimal dilutions up to $10^{-4}$ were made and $0.1 \mathrm{ml}$ aliquots were inoculated in triplicate onto the Petri dishes with the Sabouraud glucose agar medium with chloramfenicol $\left(0.5 \mathrm{~g} \mathrm{l}^{-1}\right)$. The dishes were kept in a thermostat at the temperature of $26( \pm 2){ }^{\circ} \mathrm{C}$. Growing colonies of fungi were counted on 3rd, 5th and 7th day. Fungi were identified according to morphological and microscopic characteristics (Pitt, Hocking, 1999; Watanabe, 2002; Leslie, Summerell, 2006).

Analyses were performed in five replications.

\section{RESULTS AND DISCUSSION}

The analyses of nut samples revealed that imported nuts were quite intensely contaminated with propagules of various fungi species. The moisture content in the nuts varied in de- pendence of their type and acquisition place. Storing conditions had the effect on the moisture content of nuts, not only their chemical composition. The highest moisture content was observed in walnuts, $13.93 \%$, while almost two times less in pistachio and hazelnuts, 6.38 and $6.76 \%$, respectively (Table 1 ). The highest fluctuations in the moisture content between the same nut samples were in walnuts - from 11.28 to $17.08 \%$.

The least number of colony forming units of fungi was detected in hazelnuts $\left(9.11 \times 10^{3} \mathrm{cfu} / \mathrm{g}\right)$ followed by peanuts $\left(11.46 \times 10^{3} \mathrm{cfu} / \mathrm{g}\right)$. In contrast, walnuts represented the highest infections of fungi $\left(20.90 \times 10^{3} \mathrm{cfu} / \mathrm{g}\right)$ (Table 1$)$. This contamination could be due to long-term storage, marketing under non-hygienic conditions of the food products in the poor environmental conditions including high moisture and temperature.

The results presented in Table 2 show the identity of fungi that was found in all nut samples. A total of 8 different fungal genera (Aspergillus spp., Acremonium spp., Cladosporium spp., Fusarium spp., Mucor spp., Rhizopus spp., Paecilomyces spp., and Penicillium spp.) and 16 species were isolated (Table 2).

Table 1. Nut moisture content and contamination with micromycetes

\begin{tabular}{|c|c|c|c|c|}
\hline Samples & Hazelnuts & Walnuts & Pistachio & Peanuts \\
\hline \multicolumn{5}{|c|}{ Moisture content, $\%$} \\
\hline 1 & $5.62 \mathrm{Ac}$ & $11.28 \mathrm{D} \mathrm{a}$ & $6.50 \mathrm{~B} \mathrm{C}$ & $8.06 \mathrm{C} \mathrm{b}$ \\
\hline 2 & $7.34 \mathrm{Cb}$ & $17.08 \mathrm{D} \mathrm{f}$ & $6.02 \mathrm{~A} \mathrm{a}$ & $7.06 \mathrm{~B} \mathrm{a}$ \\
\hline 3 & $5.92 \mathrm{~A} \mathrm{~d}$ & $16.60 \mathrm{Ce}$ & $5.94 \mathrm{~A} \mathrm{a}$ & $7.04 \mathrm{~B} \mathrm{a}$ \\
\hline 4 & $6.74 \mathrm{~B} \mathrm{a}$ & $14.74 \mathrm{D} \mathrm{C}$ & $6.22 \mathrm{~A} \mathrm{~b}$ & $11.14 \mathrm{C} \mathrm{e}$ \\
\hline 5 & $7.78 \mathrm{~B} \mathrm{f}$ & $16.38 \mathrm{D} \mathrm{d}$ & $6.96 \mathrm{~A} \mathrm{e}$ & $8.98 \mathrm{C} \mathrm{d}$ \\
\hline 6 & $6.30 \mathrm{~A} \mathrm{e}$ & $12.02 \mathrm{D} \mathrm{b}$ & $6.62 \mathrm{~B} \mathrm{~d}$ & $8.26 \mathrm{C} \mathrm{c}$ \\
\hline Average & $6.76 \mathrm{~A}$ & $13.93 \mathrm{C}$ & $6.38 \mathrm{~A}$ & $8.56 \mathrm{~B}$ \\
\hline \multicolumn{5}{|c|}{ Contamination (colony forming units), $\mathrm{g} \times 10^{3}$} \\
\hline 1 & $6.56 \mathrm{~A} \mathrm{a}$ & $19.76 \mathrm{D} \mathrm{b}$ & $12.58 \mathrm{C} \mathrm{d}$ & $10.16 \mathrm{~B} \mathrm{a}$ \\
\hline 2 & $6.88 \mathrm{~A} \mathrm{ab}$ & $22.98 \mathrm{D} \mathrm{d}$ & $11.52 \mathrm{C} \mathrm{c}$ & $10.20 \mathrm{~B} \mathrm{a}$ \\
\hline 3 & $6.88 \mathrm{~A} \mathrm{ab}$ & $20.98 \mathrm{D} \mathrm{a}$ & $10.50 \mathrm{C} \mathrm{a}$ & $9.04 \mathrm{~B} \mathrm{~b}$ \\
\hline 4 & $7.38 \mathrm{~A} \mathrm{c}$ & $20.94 \mathrm{D}$ a & $10.76 \mathrm{~B} \mathrm{a}$ & $15.00 \mathrm{C} \mathrm{e}$ \\
\hline 5 & $13.60 \mathrm{~B} \mathrm{~d}$ & $21.22 \mathrm{D} \mathrm{a}$ & $14.96 \mathrm{C} \mathrm{b}$ & $12.06 \mathrm{~A} \mathrm{c}$ \\
\hline 6 & $7.14 \mathrm{~A} \mathrm{bc}$ & $21.92 \mathrm{D} \mathrm{c}$ & $14.94 \mathrm{C} \mathrm{b}$ & $12.94 \mathrm{~B} \mathrm{~d}$ \\
\hline Average & $9.11 \mathrm{~A}$ & $20.90 \mathrm{D}$ & $12.54 \mathrm{C}$ & $11.46 \mathrm{~B}$ \\
\hline
\end{tabular}

Significant differences $(\mathrm{p}<0.05)$ among the nuts in rows are marked by different capital letters A, B, C, D.

Significant differences $(\mathrm{p}<0.05)$ among the markets in the column are marked by different lowercase letters a, b, $c, d$ 
The greatest diversity of micromycetes was detected in hazelnuts and walnuts.

Table 2. The isolated micromycetes from nuts

\begin{tabular}{|c|c|}
\hline Samples & Fungi \\
\hline \multirow{7}{*}{ Hazelnuts } & Aspergillus fumigatus \\
\hline & A. niger \\
\hline & A. versicolor \\
\hline & Fusarium sprotrichioides \\
\hline & Penicillium chrysogenum \\
\hline & Penicillium spp. \\
\hline & Rhizopus stolonifer \\
\hline \multirow{8}{*}{ Walnuts } & Aspergillus niger \\
\hline & Aspergillus spp. \\
\hline & Cladosporium spp. \\
\hline & Mucor spp. \\
\hline & Penicillium chrysogenum \\
\hline & P. crustosum \\
\hline & P. expansum \\
\hline & Penicillium spp. \\
\hline \multirow{5}{*}{ Pistachio } & Acremonium spp. \\
\hline & Aspergillus flavus \\
\hline & A. niger \\
\hline & A. fumigatus \\
\hline & Penicillium spp. \\
\hline \multirow{5}{*}{ Peanuts } & Aspergillus flavus \\
\hline & A. fumigatus \\
\hline & Aspergillus spp. \\
\hline & Mucor spp. \\
\hline & Paecilomyces variotii \\
\hline
\end{tabular}

Aspergillus, Mucor and Penicillium genera were more frequently detected than other genera of fungi. Aspergillus spp. was found in the most investigated nut samples.

Frank (1981) detected about 50 fungal species in walnuts: the most commonly occurring ones were Aspergillus flavus, A. fumigatus, A. niger, and Cladosporium sp.

Black or brown species of aspergilli were found in $90 \%$ of the investigated samples and A. niger was the most frequently isolated mold in walnuts, contaminating $80 \%$ of walnut samples (Figure). Species of Penicillium dominated in all of the walnut samples, and in many cases the plates of the lowest dilution were totally covered with Penicillium. P. crustosum was identified in $60 \%$ of the samples (Figure). P. expansum was potentially found in $50 \%$ of the samples and assessed as dominating. Potential isolates of $P$. chrysogenum were found in $45 \%$ of samples.

Aspergillus species appear to be the most frequent reported fungi from pistachios. Doster, Michailides (1994) and Heperkan et al., (1994) reported 14 Aspergillus species in pistachios (A. flavus, A. parasiticus, A. niger, A. ochraceus and others).

In the analysed pistachios and peanuts the most prevalent fungi were Aspergillus spp. (identified in $70 \%$ of the samples), and Penicillium spp. (40\%) was the predominant mould. Peanut samples were contaminated by Aspergillus flavus. Isolated fungi were the following: Aspergillus, Penicillium, Rhizopus and Mucor. The previous study revealed that the presence of Penicillium and Aspergillus in soil may be the main causes of the contaminations in peanuts. Regarding direct contact of the soil with the peanuts in growth phases, fungi can penetrate through the peanut's shell and grow there (Pitt et al., 1991). A. niger and A. flavus showed similarities where both species were found in all pistachio samples. Species of the genera Aspergillus and Penicillium occurred most frequently in the pistachio samples.

Abdel-Hafez and Saber (1993) reported the following fungi in hazelnuts: Aspergillus (A. flavus, A. fumigatus), Penicillium (P. aurantiogriseum, $P$. chrysogenum, $P$. citrinum, $P$. oxalicum), Cladosporium (C. cladosporioides, C. herbarum), Fusarium (F. equiseti, F. moniliforme, F. oxysporum), Rhizopus stolonifer, Rhizomucor pussilus.

Penicillium spp. was the predominant genus isolated from all investigated hazelnut samples. Also frequent prevalent fungi in hazelnuts were Aspergillus fumigatus, A. flavus, A. versicolor, and Penicillium chrysogenum. Some hazelnuts were contaminated by Fusarium sprotrichioides (Figure).

The frequency of isolation of the mycotoxigenic fungi may be actual danger. They possess the property of releasing toxins into the food products. A. fumigatus belongs to Aspergillus genus and produces such toxins as fumigaclavines, fumigalin, fumigatin and others. Aspergillus 


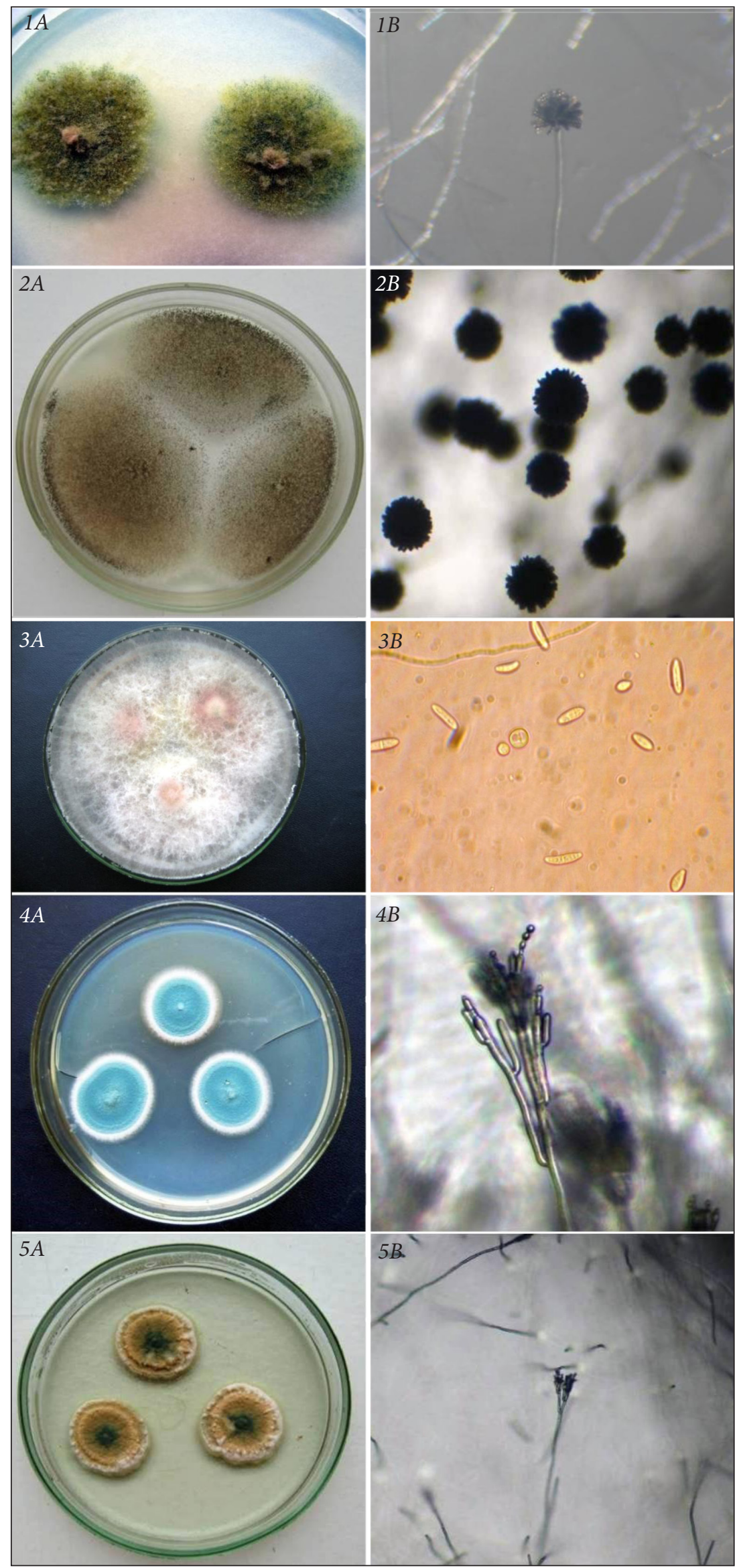

Figure. Fungi colonies (A) and conidia (B) on Sabouraud glucose agar:

1 - Aspergillus flavus;

2 - Aspergillus niger;

3 - Fusarium sprotrichioides;

4 - Penicillium expansum;

5 - Penicillium chrysogenum 
flavus produces secondary metabolites aflatoxins that have powerful teratogenic, mutagenic and hepato-carcinogenic effects. About $10 \%$ of hazelnut samples were contaminated by Fusarium sporotrichioides which is a producer of trichothecenes and zearalenone. Some species of the Penicillium genus actively producing toxins are $P$. chrysogenum that produces roquefortine $\mathrm{C}$, PR-toxin, xantocillin and $P$. expansum which is able to produce patulin and citrinin.

\section{CONCLUSIONS}

The results of this study showed that nut contamination with fungi was prevalent especially in high moisture content nuts. Storing conditions of nuts have effects on moisture content and contamination with fungi in the same nut type:

1. The highest moisture content was observed in walnuts, $13.93 \%$, while almost twice less in pistachio and hazelnuts, 6.38 and $6.76 \%$, respectively.

2. The least number of colony forming units of fungi was detected in hazelnuts $(9.11 \times 103 \mathrm{cfu} / \mathrm{g})$ followed by peanuts $(11.46 \times 103 \mathrm{cfu} / \mathrm{g})$. Walnuts represented the highest infections of fungi $(20.90 \times 103 \mathrm{cfu} / \mathrm{g})$. The greatest diversity of micromycete species was detected in hazelnuts and walnuts.

3. A total of 8 different fungal genera (Aspergillus spp. Acremonium spp., Cladosporium spp., Fusarium spp., Mucor spp., Rhizopus spp., Paecilomyces spp., and Penicillium spp.) and 16 species were isolated from nuts. Aspergillus spp. was found in the most investigated nut samples.

Received 5 October 2015 Accepted 26 November 2015

\section{References}

1. Abdel Hafez AI, Saber SM. Mycoflora and mycotoxin of hazelnut (Corylus avellana L.) and walnut (Juglans regia L.) seeds in Egypt. Zentralbl Mikrobiol. 1993; 148: 137-47.
2. Abdula NQF. Evaluation of fungal flora and mycotoxin in some important nut products in Erbil local markets. Res J Environ Earth Sci. 2013; 5(6): 330-6.

3. Christensen CM, Meronuck RA. Maintenance of quality in stored grains and seeds. Minnesota: The University of Minnesota Press; 1986.

4. Sperber WH, Doyle MP. Compendium of the Microbiological Spoilage of Foods and Beverage. Springer; 2009.

5. De Koe WJ, Sanson RA, Egmond PV, Gilbert J, Sabino M. Proceedings of the International IUPAC Symposium on Mycotoxins and Phycotoxins. Guarja, Brazil; 2000. p. 21-5.

6. D'Mello JPF, Macdonald AMC. Fungal toxins as disease elicitors. In: Rose J, editor. Environmental Toxicology: Current Developments. Amsterdam: Gordon and Breach Science Publishers; 1998. p. 253-89.

7. Doster MA, Michailides TJ. Aspergillus moulds and aflatoxins in pistachio tree in California. Phytopathology. 1994; 84(6): 583-90.

8. Frank HK. Moulds and mycotoxins in nuts and nut products. Schimmelpilze and mycotoxin in Nuessen und daraus hergestellten producten. In: Mycotoxin in lebensmitteln. Federal Republic of Germany; 1981. p. 397-414.

9. Heperkan D, Aran N, Ayfer M. Mycoflora and aflatoxin contamination in shelled pistachio nuts. J Sci Food Agric. 1994; 66: 273-8.

10. Hocking AD, Pitt JI. Fungi and mycotoxins in foods. In: Orchard AE, editor. Fungi of Australia. Vol. 1B. Introduction - Fungi in the Environment. Canberra: Australian Biological Resources Study; 1996. p. 315-42.

11. International Commission on Microbiological Specifications for Foods. Microorganisms in Food 6 - Microbial Ecology of Food Commodities. London: Blackie Academic \& Professional; 1998. p. 356-78.

12. Jay JM, Loessner MJ, Golden DA. Modern food microbiology. New York: Springer; 2005.

13. Leslie JF, Summerell BA. The Fusarium Laboratory Manual. Iowa: Blackwell Publishing; 2006. 
14. Phillips DJ, Mackey B, Ellis WR, Hansan TN. Occurrence and interaction of Aspergillus flavus with other fungi on almonds. Phytopathology. 1979; 69: 829-31.

15. Pitt JI, Hocking AD. Fungi and Food Spoilage. 2nd ed. Gaithersburg, Maryland: Chapman and Hall; 1997.

16. Pitt JI, Hocking AD, Samson RA, King AD. Recommended methods for the mycological examination of foods. In: Modern Methods in Food Mycology. Amsterdam: Elsevier Science Ltd.; 1992.

17. Pitt JI, Hocking AD. Fungi and Food Spoilage. 2nd ed. Chapman and Hall; 1999.

18. Raudonienè V, Lugauskas A. Micromycetes on imported fruit and vegetable. Bot Lith. 2005; 7: $55-64$.

19. Scott PM. Fumonisins. Int J Food Microbiol. 1993; 18: 257-70.

20. Watanabe T. Pictorial Atlas of Soil and Seed Fungi. Morphologies of Cultured Fungi and Key to Species. 2nd ed. CRC Press LLC; 2002.

\section{Aurimas Krasauskas, Aurelija Paulauskienè, Živilè Tarasevičienẻ}

\section{RIEŠUTŲ UŽKRĖSTUMAS MIKROMICETAIS}

\section{Santrauka}

Riešutai yra vienas labiausiai vartotojų mėgstamų maistingų produktų, kurių sudètyje yra daug riebalų ir baltymų. Dèl juose esančio mažo drègmès kiekio jie nèra gera terpé mikroorganizmų vystymuisi, todèl yra atsparūs mikrobiologiniam gedimui. Tirti šešiose skirtingose Kauno prekybos vietose įsigyti keturių rūšių riešutų mėginiai. Drègmès kiekis riešutuose nustatytas mėginius džiovinant $103( \pm 2)^{\circ} \mathrm{C}$ temperatūroje šešias valandas. Siekiant nustatyti mikromicetų kolonijų skaičių, skiediniai buvo pasèti ị mitybinę terpę. Mikrobiologinè analizè atskleidè, kad importuoti riešutai yra gausiai užteršti įvairių genčių mikromicetais. Drègmès kiekis riešutuose priklauso nuo jų rūšies ir ịsigijimo vietos. Didžiausias drègmès kiekis nustatytas graikiniuose riešutuose - 13,93\%, beveik perpus mažesnis pistacijų ir lazdynų riešutuose - atitinkamai 6,38 ir 6,76 \%. Mažiausias mikromicetų pradų skaičius nustatytas lazdynų riešutuose - 9,11 × 103 bei žemès riešutuose - 11,46×103 ksv/g. Didžiausia mikrobiologine tarša išsiskyrė graikiniai riešutai, čia bendras mikromicetų pradų skaičius sudarè $20,90 \times 103 \mathrm{ksv} / \mathrm{g}$.

Riešutuose rastos aštuonios mikromicetų gentys (Aspergillus spp., Acremonium spp., Cladosporium spp., Fusarium spp., Mucor spp., Rhizopus spp., Paecilomyces spp., Penicillium spp.) ir išskirta šešiolika jų rūšių. Didžiausia mikromicetų įvairovẻ nustatyta lazdynų ir graikiniuose riešutuose. Aspergillus, Mucor ir Penicillium genčių mikromicetai vyrauja visuose riešutų méginiuose, tačiau dominavo Aspergillus genties mikromiceai.

Raktažodžiai: Aspergilus, drègmès kiekis, graikiniai, lazdynų riešutai, pistacijos, žemès riešutai 